\title{
The rise of China and contestation in global tax governance
}

\section{Rasmus Corlin Christensen \& Martin Hearson}

To cite this article: Rasmus Corlin Christensen \& Martin Hearson (2022): The rise of China and contestation in global tax governance, Asia Pacific Business Review, DOI: 10.1080/13602381.2022.2012992

To link to this article: https://doi.org/10.1080/13602381.2022.2012992

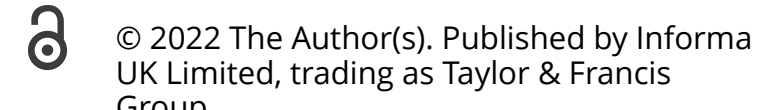
Group.

巴nublished online: 14 Jan 2022.

Submit your article to this journal $₫$

Џ Article views: 214

Q View related articles $\square$

View Crossmark data ¿ 


\title{
The rise of China and contestation in global tax governance
}

\author{
Rasmus Corlin Christensen (D) ${ }^{\mathrm{a}, \mathrm{b}}$ and Martin Hearson (iD) \\ aDepartment of Organisation, Copenhagen Business School, Copenhagen, Denmark; ${ }^{b}$ Institute of \\ Development Studies, University of Sussex, Brighton, UK
}

\begin{abstract}
This paper examines the relationship between China's changing economy and its global business tax diplomacy. Three trends dominate: China is becoming a net capital exporter, emerging as a major consumer market, and is home to digital giant firms including Baidu, Tencent and Alibaba. The resulting drive to promote both 'going out' and 'bringing in' foreign direct investment has led China to engage selectively and strategically with Western-led institutions. We show how China variously challenges, defends, and develops alternatives to global tax standards in three cases: global efforts to tackle corporate tax avoidance, bilateral tax treaty negotiations, and administrative tax cooperation.
\end{abstract}

\section{ARTICLE HISTORY}

Received 12 May 2020

Accepted 12 November 2021

\section{KEYWORDS}

Belt and Road Initiative;

China; diplomacy; digital economy; economic development; taxation

\section{Introduction}

In its 'Made in China 2025' strategy, China's State Council set out its goal for the next decade to become a major global power, 'master[ing] core technologies in key areas', such as information technology, infrastructure, and manufacturing (State Council of the People's Republic of China 2015, 7). Operationalized with the Belt and Road Initiative (BRI) at the core, the strategy hinges on radically changing China's position in the global investment landscape and its domestic corporate sector as a whole, 'combining the principles of "going out" and "bringing in"' multinational enterprises (30). Tax policy is critical to both, since the tax system shapes incentives for inbound and outbound investment. As a consequence, and as a strategic corollary, China engages in new ways with global rules and norms governing corporate taxation and tax havens, seeking to support, protect and enable its economic ascension.

Recent debate over the taxation of international business, however, has focused on the importance of the United States and its large tech firms in shaping the global political agenda, especially as attention has turned to the rise of the digital economy, dominated by large US tech firms, principally the 'FAANGs' - Facebook, Amazon, Apple, Netflix and Google (Foss, Mudambi, and Murtinu 2018; McGaughey and Raimondos 2019; The Economist 2019). This has been animated by public dissatisfaction with their aggressive tax planning and use of tax havens, and the consequent transatlantic political spat between US and Europe over the right to tax the profits of digital firms (e.g. Christensen and Hearson 2019; Lips 2019). 
In this article we point to two ways in which a focus on China sheds new light on this story. First, global struggles over corporate taxation and tax havens have an important and distinct Chinese stamp on them, which goes beyond conventional portrayals of global tax politics as always hinging on US-Europe relations, and more broadly of China's rise as an inevitable source of conflict with the US. This point is illustrated by China's 'inimitable' interests, operationalized through highly selective and strategic political engagement in tax diplomacy (Hearson and Prichard 2018), as well as the distinct Chinese corporate organization, including how corporations are linked to the Chinese state's strategic interest (de Graaff, Ten Brink, and Parmar 2020; Rowley et al. 2017). Here, we contribute to prior work that has highlighted the mutual and variegated interdependence of China's industrial structure and its international economic diplomacy (e.g. Hung 2003; Weinhardt and Ten Brink 2020; Weiss and Wallace 2021; Wong and Chan 2002). Specifically, to balance its aims of 'going out' and 'bringing in' foreign direct investment, China is selectively a defender and disruptor of the Western-liberal status quo (Hearson and Prichard 2018).

Second, China, like the US, has its own digital champions. Although political controversy in the US and Europe has largely centred on Huawei and ByteDance (which owns Tiktok), three other Chinese companies - Baidu, Alibaba and Tencent, known as the BATs - are of comparable size and disruptive capability to the FAANGs, and much less analysed in the English-speaking world. Like their American rivals, they engage in financial engineering through offshore financial centres, and have substantial scope for contentious international tax planning. Strong protections against foreign companies' access to the Chinese digital services market mean that China is, like the US, a net exporter of digital services. Existing work on contemporary Chinese (economic) diplomacy has tended to focus on geopolitical conflict with the United States in a range of policy areas (Farrell and Newman 2019b; Lindsay 2015; Mearsheimer 2010). Yet the existence of the BATs illustrates, in part, the opposite dynamic: a convergence of interests.

To illustrate these points, we present three cases that study variation in Chinese tax diplomacy by linking China's economic and political transformations. These underscore how Chinese tax diplomacy both challenges, defends, and develops alternative paths to established Western-liberal institutions (de Graaff, Ten Brink, and Parmar 2020). This is not only across different areas of policy, as highlighted by prior scholarship, but also within the same policy area (cf. Weinhardt and Ten Brink 2020). Our first case concerns global negotiations to combat tax avoidance by multinational companies. It illustrates how Chinese tax diplomacy challenged long-standing ideas in international taxation, developed and defended by OECD countries, that had entrenched a limited remuneration of 'low-value-add', 'routine' local activities by inbound investors, a key component of tax planning strategies. More recently, the growth of China's outbound investment, notably its digital sector, complicates this agenda. China seeks to protect these companies from foreign tax claims as they internationalize. These firms now compete in the global marketplace and, importantly, take advantage of the tax planning opportunities afforded by the international tax system.

Our second case study examines bilateral tax treaties between China and its trading partners, illustrating how China is capitalizing on its increasing economic power to defend OECD norms that benefit its multinationals that are 'going out'. In negotiations with developing countries targeted by Chinese outbound investments, especially BRI 
members, China has sought to limit their taxing rights as much as possible. Mention of the BRI brings us to our third case study, the establishment of a new, China-centric forum for tax administration cooperation, the Belt and Road Initiative Tax Administration Cooperation Mechanism (BRITACOM). This illustrates China developing alternative paths to implement, influence and 'supplement' international tax norms. BRITACOM is simultaneously a means of reinforcing status quo G20/OECD tax norms by the Chinese government, and an insurgent mechanism that 'supplements existing international tax governance institutions' (Deng 2019, 17).

The paper proceeds as follows. In the next section, we outline the key dimensions of China's changing position in global trade and investment, emphasizing its newfound role as a global net capital exporter, and the growth of its digital sector. The following section discusses the domestic tax policy base that has enabled and supported China's economic transformation, and which forms the basis for its global tax diplomacy. Next, we mobilize these economic transformations and domestic policies in studying how Chinese tax diplomacy strategically challenges, defends, and develops alternatives to established liberal ideas in our three cases. Finally, we discuss and conclude on the implications of our argument. We highlight how structural changes in the Chinese economy shape different, selective strategies of engagement with international policy-making, providing lessons for scholars of the Asia-Pacific business-politics nexus as well as global tax and economic politics at large.

\section{The changing position of China in global trade and investment}

China's rise in the global economy is one of the most significant economic stories of the last decades. In December 1978, the third plenary session of the 11th Central Committee of the Communist Party of China decided to revive the economy and open up the country to the world using a planned socialist market economic theory. The country passed Japan as the world's second-largest economy in 2011 and is projected to pass the United States as the world's largest economy before 2030 (World Bank 2013). Yet this rise is not the result of a singular growth trajectory, but rather multiple streams of economic change that are integrally linked to China's domestic policies and its position in global value chains.

Most prominently, China has established itself over the past decade as one of the world's largest capital exporters. Despite increasing economic openness fostering rapid upscaling of foreign direct investment, Chinese outward investment has increased even further, based on high domestic savings and political encouragement of foreign investment (Yi 2015). China has developed strong investment ties to both developed countries and other developing and emerging economies, growing to become the largest trading partner for the United States, Japan and South Korea, as well as Brazil, Russia and SubSaharan African as a collective. ${ }^{1}$ Notably, this global investment role reflects the Chinese state's prominence in society and corporate life, as global investment is dominated by state-owned enterprises (SOEs), such as the Sinopec Group, China National Petroleum and Bank of China, as well as the state's sovereign wealth fund, China Investment Corporation.

More recently, China's global economic presence has become marked by its emergence as a major consumer market. Bound up in this shift is the growth of its large and prominent digital sector, headlined by the innovation successes of lead firms like Baidu, 
Tencent and Alibaba (known as the BATs) (Greeven and Yip 2019). Currently, China is set to become the biggest digital trader in the world in terms of raw volume (Yang 2019), and of the 20 most valuable internet-based companies, nine are Chinese (the other 11 American) (Candelon, Yang, and Wu 2019). Strength is, in part, in the diversity of business models, as China's digital giants range from digital conglomerates (e.g. Alibaba), across infrastructure (e.g. Huawei) and transportation (e.g. Didi Chuxing), to search (Baidu) and social media (e.g. ByteDance).

Global expansion is significant. For instance, Tencent and Alibaba between them have data centres in Australia, Indonesia, Japan, Korea, Malaysia, Singapore and Thailand, as well as further afield in the North and South America, Europe, India and the Middle East. ${ }^{2}$ Alibaba mirrors China's 'bringing in, going out' approach, as its global expansion aims to bring more foreign brands to Chinese consumers as well as to expand its retail presence abroad (Hanbury 2019). Tencent, meanwhile, has a growing share of overseas markets in online payment and gaming (Sun 2019). However, questions remain as to the foreign market penetration of Chinese digital firms, as they focus expansion on a concentrated presence in the regional markets of the Asia-Pacific (Dvorak and Woo 2019). This may help us understand why only Huawei and, more recently, TikTok have emerged as high-profile, globally-recognized brands, and why each has been met with huge controversy in Western markets (Gapper 2019): Huawei for its risk to cyber security; TikTok for its risk to data privacy.

So while the focus in international taxation has been on American tech firms' aggressive tax planning and use of tax havens, this internationalization of Chinese digital giants opens up similar opportunities, and for further global tech contestation (Farrell and Newman 2019a). The BATs and other Chinese firms have a significant footprint in tax havens (Sutherland, Hennart, and Anderson 2019; Buckley et al. 2018). To reduce tax burdens on outbound investment, China-based digital firms selling to overseas consumers may, for instance, use a Hong Kong subsidiary to reach overseas markets and avoid physical presence or dependent agents there, limiting local ('source') taxation in those markets, while taking advantage of Hong Kong's low corporate income tax rate and preferential tax rates for both individual employees and for dividends distributed from Hong Kong to China. In general, Hong Kong plays a significant role for investments inbound to and outbound from China, similar to the Netherlands and Luxembourg for European investments, and Ireland and the Caribbean for US investments (Garcia-Bernardo et al. 2017). As an established international financial centre, Hong Kong provides easy access to finance, geographic proximity and cultural connections with South-East Asia and the BRI economies. Many China-based internet platforms, e-commerce, and education companies access foreign capital by listing on foreign stock exchanges, and use Hong Kong and Cayman Islands companies to structure their offerings. Hong Kong companies within the structure minimize withholding taxes on dividends paid from mainland China (Gillis and Oqvist 2019).

At home, China is also transitioning from a focus on local production-heavy ('factory') development towards a focus on local market-heavy development. This is in step with China's unparallelled population and its growing purchasing power, which had already led it to become the largest energy consumer and producer in the world (EIA 2015) The market-based transition prompts an emphasis on the value-added of the Chinese market, 
unique in its growth, profitability and integration into global value chains, and the power these dimensions enable Chinese policy-makers and firms in the global political economy (Hearson and Prichard 2018).

This also entails a shift from manufacturing-only value chains and towards complete Chinese value chain, heavily featuring research and development (R\&D) as well as local marketing (Sun et al.2007), fostered by increased political focus on upscaling the national corporate sector and accession to the global trade regime providing an increasingly stable investment environment (Walsh 2007). Local innovation is one key component here, as China has become an innovation-driven economy following Xi Jinping's 'Chinese Dream' (Xi 2014). This has meant a rapid expansion of the share of the economy founded on innovation, intellectual property and other intangibles (Kennedy 2016; Wong and Chan 2002; Yang et al. 2012).

The Chinese consumer market is also a target of inward investors, keen to take advantage of the existing market as well as to position themselves for the future. Consumer market growth is six percent per year (WEF and Bain \& Company 2018). The growing urban middle class is one major target, and by one measure at least already spends more in total than that in the US (Kharas 2017). This is a relatively untapped market with a rapidly increasing disposable income. For example, more new passenger cars were sold in China in 2019 than in the EU and US combined, in spite of a fall in Chinese sales that year (OICA 2020). There is particular growth in online sales of imported consumer goods, which rose 30\% in 2019 in spite of trade tensions with the US (Lannes and Deng 2019).

Digital services are an exception to the story of 'bringing in'. China is the world's largest digital market, and its shift to digital consumption is likely to be accelerated by the response to Covid-19 (Ho et al. 2020). Unlike most other countries, however, access to its market is highly regulated, primarily for political reasons but with the effect that Chinese firms are effectively protected from external competition (Gao 2018). Until recently, China has opposed talks on liberalization of data flows and has been exporting its own approach to governments as part of a 'Digital Silk Road' (Aaronson and Leblond 2018). As China's largest digital services firms have begun to expand globally, however, this position has softened and at the last minute it supported the new WTO negotiations (Foroohar 2019).

These economic dimensions fundamentally shape the engagement of the Chinese state and Chinese firms with the international economic system and its political foundation. Here, China's historical development and relation to economic globalization has been marked by variously challenging, defending and developing alternative paths to the Western liberal economic order (de Graaff, Ten Brink, and Parmar 2020). To illustrate, one focal point of this engagement has been China's integration into the global trade regime, hallmarked by its admission into the World Trade Organization in 2001. WTO membership has enabled inward and outward integration of firms into global value chains, yet has been marked by both highly selective negotiation, implementation and enforcement across corporate sectors and policy areas, depending on the domestic political and economic context. For instance, where sectors are closer connected to the Chinese state, or more in need of domestic protection, China is more likely to contest liberal trade rules, as evidenced by the government's more favourable stance towards liberalization of tariffs in China's globally competitive IT industry as compared to its weaker 
national steel sector (Weinhardt and Ten Brink 2020). Similarly, China's enforcement of WTO-mandated intellectual property protections, to which it signed on, depends both on varying local law enforcement capacity and the degree to which products cause harm to consumers (Hung 2003). This mirrors a general pattern in which China is, at once, articulating its role in the global economy as 'the wave of the future' and maintaining its protection as a developing country with fewer global responsibilities (Wade 2011).

\section{Domestic tax foundations for China's changing economy and diplomacy}

Throughout its ascension, domestic tax policy has been a cornerstone enabling both China's large-scale economic transformation and its reconfigured global tax diplomacy. In this section, we set out these domestic tax policy foundations, which have been marked by measures to stimulate inbound investment, followed by a rebalancing of the corporate tax system, continued tax incentives for strategically important sectors, and (some) convergence with global tax standards.

In the early stages of opening up the Chinese economy, in the late 1970s, the central government focused on deploying tax policy (along with other financing policies) to improve macro-economic regulation and attract inbound investment, fostering integration into global supply chains and local upscaling. To strengthen the opening-up policy, the 1991 Income Tax Law for Enterprises with Foreign Investment and Foreign Enterprises granted substantial tax reliefs to foreign investment. To attract foreign direct investment in the Special Economic Zones (SEZs) started in the southeastern coast Shenzhen, Zhuhai, and Xiamen - foreign investment in the SEZs was eligible for a $15 \%$ corporate income tax rate, compared to the national statutory rate of $33 \%$. Moreover, to incentivize investment in manufacturing, foreign investors scheduled to operate for more than ten years were eligible for an income exemption in the first and second years from the year beginning to be profitable and allowed a $50 \%$ reduction in the third through fifth years.

By the turn of the century, the economic context had changed significantly, as the Chinese economy had grown more mature and competitive. Moreover, China joined the WTO in 2001, leading to increasing criticism (and legal demands) to address the skewed tax treatments between foreign and domestic business investment. As such, in January 2008, the unified Enterprise Income Tax Law standardized the tax rate at 25\%, replacing the dual track system which granted more favourable income tax treatments to foreign invested companies and foreign enterprises, compared with their Chinese counterparts (van der Hoek, Kong, and Li 2008). In addition, the focus of preferential tax treatments was changed from the source of investment capital to industries and business segments.

As a result of changing policies and a broadening of the Chinese business tax system, $80 \%$ of the total national tax revenue comes from corporate income tax and indirect taxes on goods and services, which are collected by businesses. In contrast, only around seven percent comes from personal income tax, compared to an OECD average of around 30\% (ICTD/UNU-WIDER 2020). Companies have complained that tax burdens in China have reached economically lethal levels. In 2016, Cao Dewang, CEO of Fuyao Glass, stated that China's net tax burden was 35\% higher than that in the US, which also caused concern that large manufacturers might consider relocating factories away from China (Li 
2017). Zong Qinghou, the founder of the Chinese beverage giant, the Wahaha Group, similarly stated that Wahaha paid over 500 types of national, provincial and local taxes and fees in total in $2016 .^{3}$

In response, the Chinese government has recently started to focus on cutting taxes and reaffirming business incentives to invest in China, emphasizing that the priority is to encourage investment rather than imposing taxes that might limit business expansion. While businesses are generally subject to corporate income tax at 25\%, strategically important sectors with a clear and important internationalization path are offered lower rates. Multiple types of tax incentives and reductions are available to lower effective tax rates below the $25 \%$ headline rate (Dai 2019). For instance, to attract more MNEs to transfer design, $R \& D$, procurement and management-related business and functions to China, the State Administration of Taxation (SAT) offers a 15\% corporate income rate to qualified 'technology advance service enterprises' engaging in service outsourcing businesses. ${ }^{4}$ In addition, the State Council has added more cities in the free-trade zones (FTZ) agenda and strengthened the development of the FTZs across the country (Ho and Lu 2019). Shanghai FTZ and Hainan free-trade port in particular aim to become main freetrade centres in mainland China to compete with Hong Kong and Singapore (Leng and Zheng 2020). Numerous tax reliefs are granted for businesses in the FTZs, and foreign investment is a substantial beneficiary.

This 'tax cut' agenda has only become reinforced in the wake of the Covid-19 outbreak, as businesses in China have been substantially affected. Digital firms in mainland China commonly locate in free-trade zones and apply for 'high-tech enterprise' status due to their focus on R\&D for technology advancement, which qualifies them for the lower corporate income tax rate. Moreover, by purchasing and processing goods and managing inventory in mainland China, Chinese multinationals gain access to cost savings and market premiums.

With tax cuts and base broadening, China's corporate tax policies have increasingly converged to its peers in the OECD, as part of its integration into the global trading system and the international tax community. Here, the SAT has also adopted rules to discourage corporate tax avoidance - a key focus of the OECD - by revising rules on indirect asset transfers, controlled foreign corporations (CFC), transfer pricing, and permanent establishments (State Tax Administration 2018a). These rules address tax avoidance risks for both inbound and outbound investments, in line with OECD standards. For instance, outbound investments from China need to accord with CFC rules stipulating that the profits of the CFC would be deemed to have been distributed to the investor and be subject to corporate tax in China if the effective tax rate of a foreign subsidiary is lower than $12.5 \%$. Moreover, in alignment with OECD guidelines, rules requiring businesses to file documentation of their tax and transfer pricing practices have been tightened, and to reduce complexity and encourage taxpayers to meet global standards, the SAT has adopted a 'cooperation model', helping foreign businesses in China comply with local regulation (Teoh and Wang 2019).

Yet due to limited administrative capacity and the SAT's lack of experience, certain new practices that are receiving a lot of attention in OECD countries remain underdeveloped in China (Wang, Sun, and Li 2017). One area is advance pricing arrangements (APAs). These are pre-agreed deals between tax administrations and a taxpayer for the pricing of transactions for tax purposes, with the aim to promote tax certainty. Despite the high 
priority devoted to APAs by OECD states, APAs are not much used in China. Its first bilateral APA was signed with the Netherlands in 2016. In its annual report on Advance Pricing Arrangements (State Tax Administration 2018b), the SAT anticipates having more APAs relating to the transfer of intangibles, services, and financial assets. Also, the SAT is more likely to conclude the APA arrangement that is for new types of related-party transactions or for new counterparty authority country locations that would help the agency to expand its experience and knowledge in the APA procedure.

\section{Chinese global tax diplomacy}

Both Western and Chinese scholarship on global tax diplomacy focuses on states' need to reconcile three objectives (Deng 2019; Genschel and Rixen 2015). First, states cooperate to prevent double taxation, which is caused by incompatibilities between their tax systems, and might deter cross-border investment if unresolved. Second, they also cooperate to prevent international tax avoidance and evasion, which cost them tax revenue. Third, they seek to retain their own sovereignty over tax policy and administration, a goal that is in tension with the other two.

China's approach to tax cooperation during the 21st century is best described as one that prioritizes its own sovereignty, seeking to participate in global discussions strategically on its own terms. Following its economic transformations, and in common with the United States, China now has markets that are large and attractive enough that it can act unilaterally and enjoy a powerful voice. It can diverge from globally agreed rules designed to prevent double taxation, relying on other states to adapt those rules to accommodate it, or on investors to tolerate double taxation as a price for access to its profitable markets. In negotiating bilateral tax agreements, it can drive a hard bargain with developed and developing countries alike.

In this section, we survey the link between China's economic and political transformations through variation in Chinese tax diplomacy, which strategically challenges, defends, and develops alternatives to established liberal ideas. We contend that China's rise to status of a global net capital exporter, its mix of inbound and outbound investment priorities, its homegrown digital giants, in combination with its domestic tax policy foundations, underpin its global tax diplomacy. Three episodes illustrate these points: global efforts to tackle corporate tax avoidance, bilateral tax treaties, and administrative cooperation. First, China has selectively challenged and defended Western-consensus tax norms in global negotiations, depending on the extent to which those ideas limit the Chinese tax take from strategically important sectors, or smooth the path for the expansion of Chinese multinationals. Second, China has defended those same ideas in bilateral tax treaties where they enable China to protect its outbound investments, particularly when China's economic power puts it at a negotiating advantage with less developed countries. Third, China has sought to develop alternative tax diplomacy paths where its economic interests in the outbound investments of SOEs and digital giants align with its political interests in Chinese-centric administrative tax cooperation.

\section{Challenging Western tax ideas in global reform to re-align corporate tax revenues}

When the G20 and OECD launched a programme of reforms to global corporate tax rules in 2013, China and other emerging markets had equal seats at the table for the first time. The main aim of these reforms was to deal with the problem of 'Base Erosion and Profit 
Shifting' (BEPS), the exploitation of globally agreed tax rules by multinational firms to avoid tax. To maximize the chances of reaching a quick agreement, the action plan published in 2013 emphasized that the aim was to prevent tax leakages caused by gaps and mismatches in existing rules, and 'not directly aimed at changing the existing international standards on the allocation of cross-border income' (OECD 2013, 11). While G20 and OECD states could agree on tackling tax avoidance, they did not relish the prospect of revisiting the distributional settlement underlying international tax rules, effectively shaping the global allocation of corporate tax revenues. Moreover, the dense technical community of experts from the OECD countries made it hard for 'outsiders' to effectively shape discussions (Christensen 2020a).

For China, however, that distributional settlement was also at issue, and the government tried to make the mark despite barriers to influence. During the negotiations, China promoted the concept of 'location-specific advantages' (LSAs). It was already applying LSAs in its domestic regulations implementing OECD rules, even though the SAT contravened those rules. The claim underlying LSAs was that foreign firms were uniquely profitable in China, a result of 'location savings' in manufacturing and 'market premiums' in retail (Tizhong and Wang 2013). It also argued that international tax rules did not adequately recognize what are often referred to as 'marketing intangibles', where affiliates of a multinational generate intellectual property in the form of localized brands and expertise. Because of this, the SAT claimed that foreign multinationals were taking advantage of international tax rules to limit their tax liabilities in China, and that it should have more taxing rights over these firms' Chinese operations than international tax rules granted it. When China first outlined these concepts in a United Nations document in 2013, both India and South Africa expressed support. In principle, changes that shift taxing rights towards countries in both the manufacturing and retail stages of global value chains should benefit most developing countries, but in particular countries like China due to its large local market base and distinct corporate organization. $^{5}$

OECD members were willing to meet China halfway. In particular, they sought to keep hold of their taxing rights over multinationals' activities in the Chinese consumer market. International tax rules were changed to recognize location specific advantages in manufacturing stages of the value chain, but not market premiums. China, meanwhile, has continued to implement its own approach to LSAs and marketing intangibles, despite the agreement. As three officials from the State Administration of Taxation (SAT) wrote after the project's conclusion in 2017:

[S]ome important questions remain unanswered. For example, has the [BEPS] project resolved all the differences between developed and developing countries in transfer pricing issues? Also, have the international tax rules become fairer and less biased as a result of the reform? (Wang, Sun, and Li 2017, 549)

In the second wave of negotiations, which began in 2018, China's situation has subtly altered. Raising a 'fair' share of tax from its consumer market is still a priority, and China has not waited for international cooperation to achieve it. As its outbound investments grow, however, it has an increasing interest in protecting its multinationals from additional taxes overseas, whether they are imposed unilaterally as more and more states are choosing to do, or multilaterally through a new agreement at the OECD. In the same 
manner as the US, therefore, China's interest is in supporting just enough global cooperation so that other states adopt an agreed lowest common denominator and refrain from more aggressive unilateralism (Hakelberg 2020, chapter 6).

The new negotiations respond to a rising tide of public dissatisfaction concerning large digital corporations such as the FAANGs. Unilateral measures to tax the inbound activities of digital companies have proliferated (OECD 2018, 2019). Many of the proposed measures will impact the BATs as well, a development that goes largely under the radar of public debate. On the inbound side, China, alongside the US, stands out because it has not implemented a unilateral digital services tax. This is not surprising, because Chinese restrictions on foreign companies' access to its digital services markets mean either that they are not present at all, or that they have localized operations that are taxable under existing multilateral rules (Lee-Makiyama 2018).

The new OECD/G20 project has two aims. First, to prevent companies from gaining a large foothold in a country's digital market (measured by the volume of sales, or number of users, of online services) without paying significant tax there. To do so, it is necessary to redistribute some 'taxing rights' to the market country from the offshore financial centres to which digital firms are adept at shifting their profits, as well as from the countries where they are headquartered. The second aim is to further prevent tax avoidance by ensuring that all large companies pay a minimum effective rate of taxation, both at global level and in each country where they operate.

Looked at in terms of foreign direct investment, China's position on these proposals is ambiguous. They will enhance its ability to tax inbound investment, but they will also raise overseas taxes on firms 'going out', something that it has been assiduously using other policy instruments to minimize. On digital services specifically, the likelihood of more losses than gains to the Chinese government is clearer. Unlike the countries driving the digitalfocused agenda, notably Europe and India, China's digitalized consumer market is not deeply penetrated by foreign firms. China has vast geographical disparities and socioeconomic variations across its regions, and the retreat of some companies, including Uber, has been the result of fierce market competition (Li 2018). As noted, China has its own digital giants on an international expansion path. And more broadly, the OECD/G20-led reform to raise taxes on the digital sector is at odds with the Chinese government's domestic policy agenda of attracting foreign investment to expand its digital economy and high-tech R\&D sectors. As China International Tax Center said, the OECD proposal aim 'too high', calling the minimum tax idea 'hypocritical' (Herzfeld 2021). Thus, it has become clear that China and the US are the key axis resisting a deal that would specifically target the digital sector - despite a continuing rhetoric of political conflict between the two powers. The key OECD official shepherding the negotiations, Pascal Saint-Amans, said about the negotiations:

What we can see are tensions, are conflicts of views. We can see an emerging view on [the issue of re-allocating taxing rights], that it should focus on digital. But we know about the US position, and the Chinese position, in particular, that it could not be ring-fenced on the digital economy. (...) We can see that it's very important to stop trade wars, and these wars would result from measures targeted on the tech companies. (OECD 2020)

In sum, Chinese engagement with global reforms to re-align corporate tax revenues illustrate its challenge to international tax norms. This strategy is in line with China's unparallelled population size and its shifting focus towards strategic support for and 
development of local market-heavy services and a globally competitive digital sector economic foundations that China has sought to protect in global negotiations. Specifically, the Chinese government has effectively questioned long-standing Western consensus that remuneration for local market-based activity should be very limited. Moreover, it has challenged recent global reform initiatives that hold large digital firms should be taxed less in their home country (i.e. China for Baidu, Alibaba and Tencent) and more in the countries where their sales or customers are, and that large multinationals should be subject to a global minimum effective tax rate. This tax diplomacy approach reflects China's position as a net capital exporter, and a major force in the global digital marketplace, and it aligns China with the United States against large European markets and less developed nations on the matter of special digital taxes. Moreover, it relies on Chinese domestic tax policy leanings that seek to protect strategically important sectors on a clear growth pathway.

\section{Defending international tax norms in bilateral tax treaties}

The primary way in which international tax standards filter down into enforceable, hard law is through bilateral tax treaties. These treaties do not only apply international standards; they are also distributional negotiations over taxing rights between their signatories. They can be more or less constraining on the taxing rights of the 'source' country, that is, the recipient of inward investment. For example, they limit host countries' ability to impose 'withholding taxes' on cross-border payments of dividends, interest, royalties and service fees. They prevent taxation of the profits from construction projects unless they continue for more than a certain period of time, and limit the imposition of capital gains tax on foreign companies. Each is negotiated on the basis of globally recognized models, principally one adopted by the OECD and another by a United Nations Committee of experts. The restrictions they impose on source taxing rights are determined in bilateral negotiations. China has signed over 100 such treaties, giving it one of the largest networks in the world.

In negotiations with developed countries, China has defended its source taxing rights as much as possible, in contrast to what might be characterized as the 'OECD consensus' that tax treaties should provide relatively limited taxing rights for source countries. For example, not only was its 1986 tax treaty with the United States the first to be signed by a US president rather than a lower-ranking diplomat, it was also 'particularly generous' towards China, so much so that the US Senate Foreign Relations Committee included in its official report a disclaimer stating that the treaty could not act as a precedent for subsequent negotiations with other countries (Reese 1987). Nonetheless, China cites its tax treaties with sources of inward investment as tax incentives, estimating that foreign multinationals gained tax savings of RMB 28 billion (USD 4.0 billion) as a result in 2016 (General Office of the State Administration of Taxation 2017).

Following its economic transformation, China has changed course. Its treaties have begun to expand its taxing rights as a capital exporter, at the expense of countries to which it exports capital (Li 2012). In 2015, the National Development and Reform Commission of China issued a joint statement on 'Promoting the Joint Construction of the Silk Road' with the Ministry of Foreign Affairs and the Ministry of Commerce. It proposed to 'Strengthen the negotiation of bilateral investment protection agreements 
and agreements for the avoidance of double taxation agreement' (cited in Deng 2019, 15). China's treaties with developing countries are frequently among the most restrictive that they sign. When Uganda reached an agreement with China in 2012, Ugandan negotiators were so anxious about its potential consequences that they paused all negotiations while the government undertook a full review of its treaty network (Hearson and Kangave 2016). That treaty has never been ratified. China's agreement with Zambia was tough enough that it provoked a renegotiation by the UK, which wanted to match the lower withholding tax rates that Zambia had accepted for Chinese firms (Hearson 2021a).

Figure 1 uses an index of source taxing rights, measuring how much a tax treaty protects the taxing rights of the source country. It shows how a clear divergence has opened up between India and China in their negotiations with developing countries. China's recent treaties with developing countries impose considerably more curbs on taxing rights than India's. Indeed, China is now one of the toughest negotiators of all with countries that are likely to be net recipients of its investment. Cambodia, for example, has signed seven tax treaties since its first in 2016, most of them with a strong source tax orientation. Its agreements with China and Korea stand out as imposing the greatest restrictions on source taxing rights. The China-Cambodia agreement, in particular, includes a narrow definition of 'permanent establishment' that sets a high bar for physical presence in Cambodia before Chinese firms can be brought into the corporation tax net.

An SAT document published in 2017 describes how 'China's tax authorities (...) build a network of global tax conventions in support of the Belt and Road Initiative' (General Office of the State Administration of Taxation 2017). It explains that China has signed treaties with $54 \mathrm{BRI}$ countries, and the SAT is actively engaging with businesses and the governments of these countries to implement them. In particular, the SAT is committed to assist Chinese companies to negotiate with overseas tax authorities to safeguard the legal rights and interests of the Chinese companies investing overseas, to publish BRI countries' tax laws and regulations for Chinese companies' reference, and to strengthen cooperation

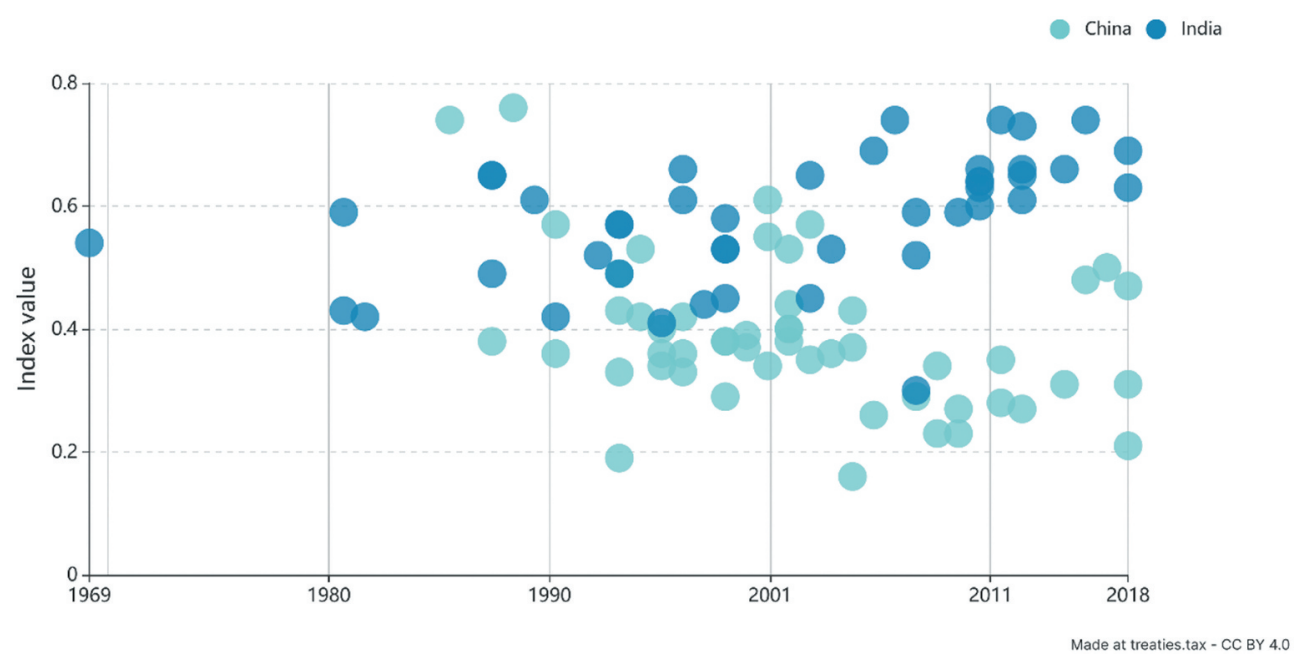

Figure 1. China and India's tax treaties with developing countries measured using an index of source taxing rights. Source: Tax Treaties Explorer (Hearson 2021b). 
with the overseas tax authorities in the BRI countries. Examples of countries that have gained tax reductions as a result are taken from Ethiopia, Malaysia and Kazakhstan. HuaJian Group, a footwear manufacturer based in Guangdong with overseas operations in Ethiopia, saves US\$300,000 in tax on dividends paid from its Ethiopian subsidiary back to China. 'We will continue to negotiate, execute and revise tax conventions based on the changes in conditions and the new scenarios encountered by enterprises, and conscientiously implement the tax conventions', a senior SAT official is quoted as saying. 'Globally, we will spur overseas tax authorities to offer convenience to Chinese enterprises so that they can enjoy the treatment set forth in the tax conventions'.

One key benefit tax treaties provide to investors is the Mutual Agreement Procedure (MAP), a legal framework that allows for diplomatic negotiations between governments to settle disagreements about how they should be taxed. The SAT emphasizes that it 'makes full use of the bilateral negotiation mechanism under the tax conventions to help taxpayers settle tax-related disputes and reduce tax costs for taxpayers going global and key projects under the Belt and Road Initiative' (General Office of the State Administration of Taxation 2017). Between 2013 and 2017, 181 MAP negotiations were conducted, saving businesses RMB 13.2 billion (USD 1.8 billion), according to the same document. Chinese scholars have also suggested that the SAT expand its use of bilateral APAs, which are conducted through the MAP mechanism, along the BRI in order to improve tax certainty, avoid dispute resolution, and lower tax compliance costs (Cao 2020). Indeed, China's APA programme appears focused on the BRI, rather than on the West: two thirds of its bilateral APAs are with Asian countries (State Tax Administration 2018b).

In sum, the case of bilateral tax treaties represents a defending strategy in global tax diplomacy. Through bilateral tax treaties with its country partners, China has sought to limit the 'source' taxing rights of countries where Chinese companies are invested. This is especially so in negotiations with less developed countries, whose policy positions and interests now depart significantly from China's (despite China's continued self-description as a developing or emerging economy). This builds on the rapid internationalization of Chinese business and its large-scale outbound investment strategy, seen at the macrolevel in its net capital export position. And it mirrors the (selective) convergence towards OECD-defined global tax standards present in its domestic tax foundations, where China is increasingly taking up negotiating and policy positions aligned with core OECD countries, the historically dominant capital-exporting nations.

\section{Developing alternative diplomatic paths through China-centric administrative cooperation}

China has begun to build on the diplomatic foundations created by its tax treaties with BRI countries by establishing BRITACOM, the Belt and Road Initiative Tax Administration Cooperation Mechanism. Chinese Communist party-sponsored publications commonly describe BRITACOM as a way in which China is taking responsibility as a major player in the global tax community. ${ }^{6}$ One such article is by Wang Li, a former Deputy Director General of the State Administration of Taxation. He describes three phases of China's engagement with international tax. While the first phase, during the 1980s and 1990s, focused on attracting inbound investment, the second phase from the early 2000 s placed equal emphasis on inbound and outbound investment. BRITACOM appears as the 
centrepiece of the third phase, which has prioritized, 'becoming a significant country in the international landscape of taxation ... ready to shoulder the corresponding international responsibilities' (Li 2016, 73-74). Another article by an academic states, 'China has no intention of exporting its own tax systems and policies as standards, but as a major economy it does have a responsibility to build a platform for international tax cooperation that meets the demands of developing countries' (Deng 2019,17).

We can understand BRITACOM as a framework for smoothing the way for goods, services and investment flowing between China and its members, as well as a longer term institutional project. Promoting growth, trade and investment seems at the forefront in the official declaration of the first BRITACOM conference, according to which the discussions 'focused on how to build a growth-friendly tax environment that would promote economic growth while ensuring tax revenue mobilization in jurisdictions that support the Belt and Road Initiative' (BRITACOM 2019). Its current work programme covers: i) raising tax certainty; (ii) expediting tax dispute resolution; (iii) enhancing tax administration capacity; (iv) streamlining tax compliance; and (v) digitalizing tax administration. There is a strong focus on capacity building and sharing of ideas, with the creation of four tax academies.

A new parallel institution outside of the established institutions at the OECD, G20 and UN naturally suggests a divergence from those institutions in which China's influence is more diluted, and whose longstanding policy instruments reflect the historical preferences of established Western powers. As with other Chinese parallel institutions such as the Asian Infrastructure and Investment Bank, BRITACOM has so far appeared more supportive of, rather than challenging to, the global order. According to the statement from its first annual conference: 'The BRITACOM supports and reinforces prevailing international tax standards such as [those of] the OECD and UN' (BRITACOM 2019). An article in a Party-supported journal adds: 'Obviously, the BRITACOM is not creating another system of international tax governance "starting from scratch", nor is it replacing the existing international tax standards. Instead, it supplements existing international tax governance institutions and tax collection and management capabilities' (Deng 2019, 17). BRITACOM's Advisory Board includes the current and previous Director of the OECD's Centre for Tax Policy and Administration, as well as establishment figures such as representatives of the 'Big 4' global accountancy firms; among its official observers are business lobby groups and several OECD member states.

The emphasis in the current BRITACOM work programme on negotiating tax treaties and expediting dispute resolution is consistent with an approach based on smoothing the way for Chinese businesses 'going global' by developing a new, China-centric tax diplomatic approach. According to Wang Li, the goal is to '[t]ake advantage of the opportunities from the B\&R Initiative to expedite negotiation on DTAs, which will help effectively resolve tax disputes, enhance international tax cooperation and encourage Chinese enterprises to compete fairly and squarely in the global market' (Li 2016, 81). As we noted earlier, China's approach to tax treaty negotiation with developing countries is increasingly to pursue OECD-type agreements as far as possible, and so the promotion of negotiations is consistent with a view of BRITACOM as reinforcing existing international standards. Indeed, the BRITACOM website states that its work on dispute resolution will include 'endorsing' G20/OECD minimum standards in this area (BRITACOM 2020). 
The vast majority of the countries associated with the BRI are non-OECD members, in particular partners from Asia-Pacific and key targets for investment in Africa for Chinese SOEs and digital firms, in line with China's domestic tax agenda of providing especially favourable tax treatment for these strategically important sectors. Indeed, due to the priority placed on the SOEs' participation in the BRI and global investment in general, the international tax policies proposed by China via BRITACOM are likely to provide preferential treatment to SOEs through both domestic regulations and international agreements. Chinese tax scholars have argued in a Party-sponsored journal that marginal effective tax rates on capital in BRI countries would hinder the flow of Chinese direct investment to those countries (Xiao and Liping 2019). So far, China has signed treaties with the vast majority of the BRI countries, including 17 countries in the Asia-Pacific region, and the government expects to sign more tax treaties under the BRITACOM context.

Thus, with BRITACOM, China has only just begun to develop alternatives to established Western institutions. This reflects an overlap of its domestic economic foundations and aspirations, and its political interests in administrative tax cooperation (Rotblat 2019). In the long term, BRITACOM could allow China to gradually push for new international tax norms through a regional and China-centric, rather than global approach, sidestepping the influence of OECD countries. It is similar to the way in which, recently, the European Union has increasingly tried to make a Europe-specific mark on international tax policy (Christensen 2021). Two other developing country groupings, the G24 and African Tax Administration Forum, have recently taken on the role of blocs in global negotiations, though this was not their original remit (Christensen, Hearson, and Randriamanalina 2020). As one Western commentator suggested, BRITACOM 'categorically doesn't intend to establish new tax policies or rules. But it may do so anyway. If it develops solutions that work, that would set a benchmark for some of the main cross-border tax challenges that plague multinational companies and the world's big economies' (Toplensky 2020).

\section{Theoretical implications}

The case of tax diplomacy illustrates how China is distinctly and simultaneously challenging, defending, and developing alternative paths to entrenched Western-liberal institutions (de Graaff, Ten Brink, and Parmar 2020). The tax context here thus mirrors, to some extent, the broader trend of China's engagement with the global economy, at once playing along with and contesting global political-economic norms and narratives. As China and other emerging economies have risen to power in the governance of global markets, trade and investment, the prevalent view has been that this has left international organizations tasked with overseeing the global economy 'stranded in the middle' between old Western powers and emerging powers such as China (Woods 2010).

However, the situation is more muddled, with China's diplomatic engagement highly variable. On the political agenda of taxing large digital firms, China is aligned with the US. This is a stark contrast to conventional narratives of ever-present US-China conflict in global political discussions (Farrell and Newman 2019b; Lindsay 2015; Mearsheimer 2010). The growth of Baidu, Alibaba, Tencent and the like - to mirror Facebook, Amazon, Apple, Netflix and Google - illustrates the opposite dynamic: a convergence of interest. Yet in other non- 
digital areas, China continues to cast itself as a developing country in need of securing further taxing rights 'at source', where production or consumption occurs, in conflict with long-standing US and (some) European preferences for limiting those taxing rights.

Thus, whereas prior research has highlighted variation in China's engagement with global economic policy across different policy domains, our paper shows that this variation also takes place within the same policy domain (cf. Weinhardt and Ten Brink 2020), and varies with the domestic business context. This suggests a need to take account of both inter and intra-policy domain variation (Pereira 2017; Rowley et al. 2017). Understanding these dynamics will be key to informing debates on the businesspolitics nexus in China, Asia-Pacific and beyond, and to expand analyses of global tax and economic politics beyond US-centrism.

\section{Practical implications}

The tax domain underscores how Chinese diplomatic approaches are structured according to the unique characteristics of China's domestic business context. That context presents a unique mix of a large home market with an emerging business service sector, stateowned enterprises with outbound investment interests along the BRI, and digital giants on an internationalization path focused on regional neighbours in the short-term. Chinese tax policy aims, at once, to strengthen taxation of Western inbound investment and to limit taxation of important outbound investments in infrastructure and digital markets.

The growth of China's digital giants, on the back of an increasingly tech- and innovation-driven economy, is particularly instructive (Greeven and Yip 2019). Whereas existing work has emphasized American tech firms, China has its own large digital champions with capabilities for disruption and contentious international tax planning. And yet China's BATs are largely overlooked in discussions of corporate taxation. They illustrate China's changing approach to global tax negotiations, aligning its interests more closely with the United States, potentially compromising the alliances that China has sought to form with India and other large emerging markets as the leading proponent of BRICS-level cooperation. No other emerging or developing country has a remotely similar home-grown suite of digital giants. In studies of the Asia-Pacific business-politics nexus, this calls for paying attention to the individual sectors under scope of regulation or policy but also the broader mix of domestic sectors and investment involved, including how closely tied these are to government's strategic priorities (Hung 2003).

\section{Conclusions}

China has undergone a remarkable economic and political transformation, which shapes its newfound role and priorities in global diplomacy at large, and tax diplomacy specifically. Extant debates on the taxation of international business have focused on transatlantic Europe struggles over the taxation of American tech firms using tax havens. Indeed, more broadly analyses of China's rise tend to characterize it as an inevitable source of conflict with the US. This has overlooked the significance, distinctiveness and nuance of the Chinese stamp on international tax policy and the influence of its unique corporate organization. We have addressed this oversight by providing an account of the sources and nature of the new Chinese global tax diplomacy. 
This paper shows that China's transition to becoming a global net capital exporter, its emergence as a major consumer market, and the growth of its digital giant firms are key factors shaping its tax diplomacy. We observe this in China's own tax laws, in global efforts to tackle corporate tax avoidance at global tax policy institutions such as the OECD and UN, in its bilateral tax treaty negotiations, and in the China-centric administrative cooperation platform BRITACOM. These cases illustrate how China underpins selectively and strategically engages with Western-liberal institutions and norms in order to simultaneously incentivizing and maximizing its tax take from 'bringing in' foreign investment while minimizing the taxation of Chinese companies 'going out' through bilateral and multilateral negotiations. As set out by Wang Li, a former Deputy Director of the SAT, these interventions together, 'have contributed to building a new international taxation regime with Chinese characteristics that [is] commensurate with China's international status and opening-up economy' (Li 2016, 73-74).

\section{Notes}

1. World Bank World Integrated Trade Solution (WITS), 2018 data: https://wits.worldbank.org/.

2. https://intl.cloud.tencent.com/global-infrastructure; https://www.alibabacloud.com/globallocations.

3. The State Administration of Taxation (SAT), however, asserted that Wahaha only paid around 300 types of taxes, https://news.163.com/17/0118/14/CB2O7D2O0001875N.html.

4. Caishui [2017] No. 79.

5. One provincial SAT document claims the advantages that earn it extra compensation are 'unique in the world and inimitable by other small and medium-sized developing countries' (cited in Li 2015, 359).

6. 'Major player in the global tax community' expressed in Chinese is '大国税收'. This is sometimes translated in official publications as 'major power' or 'significant country'. It can also be translated as 'Great Power', but this conveys a stronger meaning than seems to be intended here.

\section{Acknowledgements}

We are grateful for the major contribution to our paper from a scholar based in China who wished to remain anonymous.

\section{Disclosure statement}

No potential conflict of interest was reported by the author(s).

\section{Notes on contributors}

Rasmus Corlin Christensen is a postdoctoral researcher in international political economy at the Department of Organisation, Copenhagen Business School. His research focuses on international taxation, expertise and professions. His work has been published in journals such as the Review of International Political Economy, Regulation \& Governance and Global Networks. 
Martin Hearson is a Research Fellow at the Institute of Development Studies, where he is International Tax Programme Lead for the International Centre for Tax and Development (ICTD). His research focuses on the politics of international business taxation, and in particular the relationship between developed and developing countries. He is the author of Imposing Standards: The North-South Dimension to Global Tax Politics, published by Cornell University Press.

\section{ORCID}

Rasmus Corlin Christensen (ID http://orcid.org/0000-0002-3735-5222

Martin Hearson (D) http://orcid.org/0000-0002-7108-7372

\section{References}

Aaronson, S. A., and P. Leblond. 2018. "Another Digital Divide: The Rise of Data Realms and Its Implications for the WTO." Journal of International Economic Law 21 (2): 245-272. doi:10.1093/jiel/ jgy019.

BRITACOM. 2019. "Wuzhen Statement." In The First Conference of the Belt and Road Initiative Tax Administration Cooperation Forum. Wuzhen, China.

BRITACOM. 2020. Expediting Tax Dispute Resolution. Britacom.Org. https://www.britacom.org/zdjj/ jkjfjj/

Buckley, P. J., L. J. Clegg, H. Voss, A. R. Cross, X. Liu, and P. Zheng. 2018. "A Retrospective and Agenda for Future Research on Chinese Outward Foreign Direct Investment." Journal of International Business Studies 49 (1): 4-23. doi:10.1057/s41267-017-0129-1.

Candelon, F., F. Yang, and D. Wu. 2019. "Are China's Digital Companies Ready to Go Global?" Boston Consulting Group. https:/www.bcg.com/publications/2019/china-digital-companies-ready-goglobal.aspx

Cao, Q. 2020. "On the Tax Treaty Serving the Belt and Road Initiative." International Taxation in China 2020 (4): 64-66.

Christensen, R. C., and M. Hearson. 2019. "The New Politics of Global Tax Governance: Taking Stock a Decade after the Financial Crisis." Review of International Political Economy 26 (5): 1068-1088. doi:10.1080/09692290.2019.1625802.

Christensen, R. C., M. Hearson, and T. Randriamanalina. 2020. "At the Table, off the Menu? Assessing the Participation of Lower-Income Countries in Global Tax Negotiations." International Centre for Tax and Development Working Paper 115. Brighton: Institute of Development Studies. doi:10.19088/ICTD.2020.004.

Christensen, R. C. 2020a. "Elite Professionals in Transnational Tax Governance." Global Networks. doi:10.1111/glob.12269.

Christensen, R. C. 2021. "The Rise of the EU in International Tax Policy." In Global Networks and European Actors: Navigating and Managing Complexity, edited by G. Christou and J. Hasselbalch, 110-126. Routledge.

Dai, Y. 2019. "China's Surprising Silence on Digital Taxation." Tax Analysts. July 11. https://www. taxnotes.com/tax-notes-today-international/digital-economy/chinas-surprising-silence-digitaltaxation/2019/07/11/29js2?highlight=china\%20beps

de Graaff, N., T. Ten Brink, and I. Parmar. 2020. “China's Rise in a Liberal World Order in Transition Introduction to the FORUM." Review of International Political Economy 27 (2): 191-207. doi:10.1080/09692290.2019.1709880.

Deng, L. 2019. "International Tax Governance and the BRITACOM." International Taxation in China 2019 (4): 12-18. doi:10.19376/j.cnki.cn10-1142/f.2019.04.002.

Dvorak, P., and S. Woo. 2019. "The World Expected a Chinese Tech Takeover. Alibaba Can't Even Conquer Vietnam." Wall Street Journal, September 9. sec. World. https://www.wsj.com/articles/ for-chinas-tech-giants-success-stops-at-the-border-11568043193 
EIA. 2015. "China International Energy Data and Analysis." US Energy Information Administration. https://www.eia.gov/international/content/analysis/countries_long/China/china.pdf

Farrell, H., and A. L. Newman. 2019a. Of Privacy and Power: The Transatlantic Struggle over Freedom and Security. Princeton, NJ: Princeton University Press.

Farrell, H., and A. L. Newman. 2019b. "Weaponized Interdependence: How Global Economic Networks Shape State Coercion." International Security 44 (1): 42-79. doi:10.1162/isec_a_00351.

Foroohar, R. 2019. Don't Be Evil: The Case Against Big Tech. London: Penguin Books Limited.

Foss, N. J., R. Mudambi, and S. Murtinu. 2018.“'Taxing the Multinational Enterprise: On the Forced Redesign of Global Value Chains and Other Inefficiencies." Journal of International Business Studies. June. doi:10.1057/s41267-018-0159-3.

Gao, H. 2018. "Digital or Trade? The Contrasting Approaches of China and US to Digital Trade." Journal of International Economic Law 21 (2): 297-321. doi:10.1093/jiel/jgy015.

Gapper, J. 2019. "TikTok Is Causing Almost as Much Panic as Huawei." Australian Financial Review, December 4. sec. technology. https://www.afr.com/technology/china-s-internet-interference-istiktok-famous-20191205-p53h3l

Garcia-Bernardo, J., J. Fichtner, F. W. Takes, and E. M. Heemskerk. 2017. "Uncovering Offshore Financial Centers: Conduits and Sinks in the Global Corporate Ownership Network." Scientific Reports 7 (1): 6246. doi:10.1038/s41598-017-06322-9.

General Office of the State Administration of Taxation. 2017. "Tax Conventions to Benefit All and Reciprocity for Long-Term Growth." http://www.chinatax.gov.cn/eng/n2367726/c2694320/con tent.html

Genschel, P., and T. Rixen. 2015. "Settling and Unsettling the Transnational Legal Order of International Taxation." In Transnational Legal Orders, edited by T. C. Halliday and G. Shaffer, 154-186. New York: Cambridge University Press.

Gillis, P., and F. Oqvist. 2019. Variable Interest Entities in China. Hong Kong: GMT Research.

Greeven, M. J., and G. S. Yip. 2019. "Six Paths to Chinese Company Innovation." Asia Pacific Journal of Management, June. doi:10.1007/s10490-018-9635-3.

Hakelberg, L. 2020. The Hypocritical Hegemon: How the United States Shapes Global Rules against Tax Evasion and Avoidance. Ithaca: Cornell University Press.

Hanbury, M. 2019. "Alibaba, the $\$ 435$ Billion Chinese Shopping Giant, Is Gunning for Amazon in Europe." Business Insider. https://www.businessinsider.com/alibaba-is-gunning-for-amazon-ineurope-2019-8

Hearson, M., and J. Kangave. 2016. "A Review of Uganda's Tax Treaties and Recommendations for Action." International Centre for Tax and Development Working Paper 50. Brighton: Institute of Development Studies.

Hearson, M., and W. Prichard. 2018. "China's Challenge to International Tax Rules and the Implications for Global Economic Governance." International Affairs 94 (6): 1287-1307. doi:10.1093/ia/iiy189.

Hearson, M. 2021a. The North-South Politics of Global Tax Governance. Ithaca, NY: Cornell University Press.

Hearson, M. 2021b. “Tax Treaties Explorer." http://treaties.tax

Herzfeld, M. 2021. "Resetting Expectations for a Digital Deal under the Biden Administration." Tax Analysts, February 1. https://www.taxnotes.com/tax-notes-today-international/digital-economy /resetting-expectations-digital-deal-under-biden-administration/2021/02/01/217st

Ho, J., D. Hui, A. Kim, and Y. Zhang. 2020. "Chinese Consumer Behavior Post-COVID-19." McKinsey. March. https://www.mckinsey.com/industries/consumer-packaged-goods/our-insights/cau tiously-optimistic-chinese-consumer-behavior-post-covid-19

Ho, K., and L. Lu. 2019. "China: China Introduces New Free Trade Zones and Improved Practices." International Tax Review, October 15. https://www.internationaltaxreview.com/article/ b1hlmhtmp7dhtb/china-china-introduces-new-free-trade-zones-and-improved-practices

Hung, C. L. 2003. "The Business of Product Counterfeiting in China and the Post-WTO Membership Environment." Asia Pacific Business Review 10 (1): 58-77. doi:10.1080/ 13602380412331288810. 
ICTD/UNU-WIDER. 2020. “Government Revenue Dataset." UNU-WIDER. https://www.wider.unu.edu/ project/government-revenue-dataset

Kennedy, A. B. 2016. "Slouching Tiger, Roaring Dragon: Comparing India and China as Late Innovators." Review of International Political Economy 23 (1): 65-92. doi:10.1080/ 09692290.2015 .1105845$.

Kharas, H. 2017. "The Unprecedented Expansion of the Global Middle Class: An Update." Brookings Institute Working Paper 100. Brookings India. https://think-asia.org/handle/11540/7251

Lannes, B., and D. Deng. 2019. "Despite Slowing GDP Growth, China's Consumers Keep Spending." Bain \& Company. December 5. https://www.bain.com/insights/despite-slowing-gdp-growthchinas-consumers-keep-spending/

Lee-Makiyama, H. 2018. "The Cost of Fiscal Unilateralism: Potential Retaliation against the EU Digital Services Tax (DST)." ECIPE Occasional Paper 05. Vol. 2018. Brussels: European Centre for International Political Economy (ECIPE).

Leng, S., and W. Zheng. 2020. "China Unveils Plan for Hainan Free Trade Hub as US Risk Grows." South China Morning Post, June 2. sec. Economy. https://www.scmp.com/economy/chinaeconomy/article/3087206/china-unveils-plan-make-hainan-free-trade-hub-hong-kong

Li, F. 2018. "Why Western Digital Firms Have Failed in China." Harvard Business Review, August 14. https://hbr.org/2018/08/why-western-digital-firms-have-failed-in-china

Li, J. 2012. "The Great Fiscal Wall of China: Tax Treaties and Their Role in Defining and Defending China's Tax Base." Bulletin for International Taxation 66 (9): 452-479.

Li, J. 2015. "China and BEPS: From Norm-Taker to Norm-Shaker." Bulletin for International Taxation 2015 (June/July): 355-370.

Li, N. 2017. "Is Excessive Tax Draining China's Manufacturing Sector of Vitality?" Beijing Review, January 19.

Li, W. 2016. "Modernization of China's International Taxation." International Taxation in China 2016 (5): $72-81$.

Lindsay, J. R. 2015. "The Impact of China on Cybersecurity: Fiction and Friction." International Security 39 (3): 7-47. doi:10.1162/ISEC_a_00189.

Lips, W. 2019. "The EU Commission's Digital Tax Proposals and Its Cross-Platform Impact in the EU and the OECD." Journal of European Integration 1-16. doi:10.1080/07036337.2019.1705800.

McGaughey, S. L., and P. Raimondos. 2019. "Shifting MNE Taxation from National to Global Profits: A Radical Reform Long Overdue." Journal of International Business Studies 50 (9): 1668-1683. doi:10.1057/s41267-019-00233-9.

Mearsheimer, J. J. 2010. "The Gathering Storm: China's Challenge to US Power in Asia." The Chinese Journal of International Politics 3 (4): 381-396. doi:10.1093/cjip/poq016.

OECD. 2013. "Action Plan on Base Erosion and Profit Shifting." http://www.oecd-ilibrary.org/taxa tion/action-plan-on-base-erosion-and-profit-shifting_9789264202719-en

OECD. 2018. "Tax Challenges Arising from Digitalisation - Interim Report 2018."

OECD. 2019. "Programme of Work to Develop a Consensus Solution to the Tax Challenges Arising from the Digitalisation of the Economy, OECD/G20 Inclusive Framework on BEPS." Paris. www. oecd.org/tax/beps/programme-of-work-to-develop-aconsensus-solution-to-the-tax-challengesarising-from-the-digitalisation-of-the-economy.htm

OECD. 2020. "Tax Talks \#15." May 4. http://www.oecd.org/tax/tax-talks-webcasts.htm

OICA. 2020. "New Passenger Car Sales, 2005-2019." International Organization of Motor Vehicle Manufacturers. http://www.oica.net/category/sales-statistics/

Pereira, V. 2017. "Journal Editors as Philosopher Kings: Duties and Responsibilities of Academics in a Changing World." South Asian History and Culture 8 (3): 360-364. doi:10.1080/ 19472498.2017.1350405.

Reese, P. D. 1987. “United States Tax Treaty Policy Toward Developing Countries: The China Example." UCLA Law Review 35 (2): 369.

Rotblat, C. 2019. "Chinese State Capitalism and the International Tax Regime." Columbia Journal of Tax Law 10 (1): 77-138. 
Rowley, C., J. Bae, S. Horak, and S. Bacouel-Jentjens. 2017. "Distinctiveness of Human Resource Management in the Asia Pacific Region: Typologies and Levels." The International Journal of Human Resource Management 28 (10): 1393-1408. doi:10.1080/09585192.2016.1189151.

State Council of the People's Republic of China. 2015. Made in China 2025 (“中国制造2025”). Beijing: State Council of the People's Republic of China.

State Tax Administration. 2018a. "Annual Report." http://www.chinatax.gov.cn/download/pdf/ swnb2018en.pdf

State Tax Administration. 2018b. "China Advance Pricing Arrangement Annual Report." http://www. chinatax.gov.cn/n810214/n810606/c4244610/5080963/files/e27ec0785264482aa1ee50e c3e9c755c.pdf

Sun, L. 2019. "4 Ways Tencent Is Expanding Beyond China's Borders." Nasdaq. https://www.nasdaq. com/articles/4-ways-tencent-is-expanding-beyond-chinas-borders-2019-12-17

Sun, Y., M. Von Zedtwitz, and D. Fred Simon. (2007). "Globalization of R\&D and China: An Introduction." Asia Pacific Business Review 13 (3): 311-319.

Sutherland, D., J. F. Hennart, and J. R. Anderson. 2019. “How Does the Routing of FDI to and via Tax Havens Confound Our Understanding of Chinese MNE Identity? A Critical Review of the Empirical Literature on Chinese MNEs." Asian Business \& Management 18 (5): 337-359. doi:10.1057/s41291019-00058-2.

Teoh, C. B., and X. Wang. 2019. "China Transfer Pricing Enforcement: Modernised Approach Matures." International Tax Review, December.

The Economist. 2019. "Bottle Shock: Tax Our Tech and We'll Blacklist Your Bubbly." The Economist, December 5. https://www.economist.com/finance-and-economics/2019/12/05/tax-our-tech-and -well-blacklist-your-bubbly

Tizhong, L., and X. Wang. 2013. "China Country Practice." In Practical Manual on Transfer Pricing for Developing Countries, 374-387. 1st ed. New York: United Nations.

Toplensky, R. 2020. "Beijing's Soft Power Push on Global Tax; the Little-Known Tax Drive Associated with China's Belt and Road Initiative Could Shape Corporate Tax Rules around the World." Wall Street Journal (Online); New York, N.Y., February 18. sec. Markets. http://search.proquest.com/ docview/2356568767/citation/FF413C8657D040C9PQ/1

van der Hoek, M. P., S. Kong, and Z. Li. 2008. "The Dual Corporate Income Tax in China: The Impact of Unification." MPRA Paper No. 11547. https://mpra.ub.uni-muenchen.de/11547/1/MPRA_paper_ 11547.pdf

Wade, R. H. 2011. "Emerging World Order? From Multipolarity to Multilateralism in the G20, the World Bank, and the IMF." Politics \& Society 39 (3): 347-378. doi:10.1177/0032329211415503.

Walsh, K. A. 2007. "China R\&D: A High-tech Field of Dreams." Asia Pacific Business Review 13 (3): $321-$ 335. doi:10.1080/13602380701291883.

Wang, X., Y. Sun, and H. Li. 2017. "China Country Practice." In Practical Manual on Transfer Pricing for Developing Countries, 547-580. 2nd ed. New York: United Nations.

WEF, and Bain \& Company. 2018. "Future of Consumption in Fast-Growth Consumer Markets: China." http://www3.weforum.org/docs/WEF_Future_of_Consumption_in_Fast_Growth_ Consumer_Markets_China.pdf

Weinhardt, C., and T. Ten Brink. 2020. "Varieties of Contestation: China's Rise and the Liberal Trade Order." Review of International Political Economy 27 (2): 258-280. doi:10.1080/ 09692290.2019.1699145.

Weiss, J. C., and J. L. Wallace. 2021. "Domestic Politics, China's Rise, and the Future of the Liberal International Order." International Organization 1-30. doi:10.1017/S002081832000048X.

Wong, J., and S. Chan. 2002. "China's Emergence as a Global Manufacturing Centre: Implications for ASEAN." Asia Pacific Business Review 9 (1): 79-94. doi:10.1080/713999176.

Woods, N. 2010. "Global Governance after the Financial Crisis: A New Multilateralism or the Last Gasp of the Great Powers?" Global Policy 1 (1): 51-63. doi:10.1111/j.1758-5899.2009.0013.x.

World Bank, ed. 2013. China 2030: Building a Modern, Harmonious, and Creative Society. Washington, DC: World Bank.

Xi, J. 2014. The Governance of China. Beijing: Foreign Languages Press. 
Xiao, L., and D. Liping. 2019. “Tax Competition and China's Direct Investment in the Countries along the Belt and Road." China's Taxation.

Yang, J., H. Liu, S. Gao, and Y. Li. 2012. "Technological Innovation of Firms in China: Past, Present, and Future." Asia Pacific Journal of Management 29 (3): 819-840. doi:10.1007/s10490-010-9243-3.

Yang, Y. 2019. "Report: China Becoming Digital Trade Leader." China Daily, April 9. http://www. chinadaily.com.cn/a/201904/09/WS5cac3974a3104842260b52e3.html '

Yi, C. 2015. "Financial Logic Explains China's Capital Exports." Global Times, March 12. http://www. globaltimes.cn/content/911662.shtml 